\title{
Aina ajankohtainen, usein vaiettu
}

\author{
Rancken, Jeena 2017. Yliluonnollinen kokemus. Tulkinta, merkitys ja vaikutus. \\ Tampere: Vastapaino. 371 sivua.
}

\section{Tuija Hovi}

S osiaalipsykologi Jeena Ranckenin teos Yliluonnollinen kokemus. Tulkinta, merkitys ja vaikutus (2017) on kattava esitys sosiologisen ja psykologisen tutkimuksen näkökulmista yliluonnollisen kokemiseen. Kysymyksessä on laaja empiirinen ja laadullinen tutkimus, joka nojaa sosiaalisen konstruktionismin ja kognitiivisen psykologian periaatteisiin. Ranckenilla ei kuitenkaan ole tarvetta selittää pois yksilön yliluonnollisen kokemuksen olemassaoloa tai kyseenalaistaa sen tärkeyttä kokijalle elämää mahdollisesti muuttavanakin tekijänä. Hänen tavoitteenaan on pikemminkin nostaa näkyviin koetun yliluonnollisen merkitys ja vaikutukset yksilön elämässä sekä sosiaalisen vuorovaikutuksen roolit tämän kokemuksen rakentumisessa.

Kielellisyys, tarinallisuus, sosiaalinen oppiminen ja kulttuurisuus raamittavat koettua ja tekevät yliluonnollisesta monitulkintaisen. Rancken selittää poikkeuksellisen kokemuksen kontekstuaalista syntymistä siten, että kokemuksen tulkinta yliluonnolliseksi asettaa samalla ihmisen itsensä suhteeseen tämän kontekstin kanssa. Tätä suhdetta kuvasi aikoinaan uskontopsykologi Hjalmar Sundén (1971) selittämällä uskonnollista kokemusta perinteen, roolin ja vastaroolin käsitteiden avulla. Ranckenin tutkimus yliluonnollisista kokemuksista ja niistä kertomisesta tämän päivän Suomessa linkittyy myös kansanuskon tutkimukseen.

\section{Yliluonnollisen kulttuurisuus, historiallisuus ja määrittelyn vaikeus}

Taustaksi tutkimusasetelmalleen tekijä on tehnyt laajan läpileikkauksen yliluonnollisen kokemuksen tutkimuksesta, minkä myötä - jälleen kerran - paljastuvat käsitteen määrittelyn haasteet. Mitä ylipäänsä on yliluonnollinen ja miten se taipuu tieteellisen tutkimuksen kohteeksi? Kuten Rancken katsauksessaan osoittaa, yliluonnollinen kytkeytyy kokemuksellisuuteen ja se on vahvasti kulttuurinen konstruktio. Se näkyy ennen kaikkea uskomuksina, uskomusjärjestelminä ja niihin liittyvänä sosiaalisena toimintana. Yliluonnollisen sijaan puhutaan myös paranormaalista, anomaliasta, abnormaalista, maagisesta, mystisestä tai metafyysisestä, koska - kuten kirjoittaja toteaa - 'yliluonnollinen' on kaikessa epämääräisyydessään hankala käsite tieteelle. Kysymyksessä on reaalimaailman tulkitseminen ei-reaalisessa viitekehyksessä. 
Yliluonnollisen kulttuurisuutta ja historiallisuutta on havainnollistettu teoksessa monin tavoin. Esimerkiksi 2000-luvulla raamatullisten "riivaajien" sijaan yllättävän moni haastateltu on kokenut "tarrahenkien" häiriköintiä. Moderni enkelikuvasto on niin ikään ammentanut paljon populaarikulttuurista. Tähän pätevät samat säännöt kuin uskontojenkin muuttumisessa - saadaan "uutta ilmoitusta", oivalletaan uusia tulkintoja, materiaaliset innovaatiot ohjaavat uskonnollisen elämän käytänteitä ja niin edelleen.

Tekijä referoi laajasti erilaisia tieteen antamia selityksiä yliluonnollisesta muuntuneiden tietoisuuden tilojen ja huippukokemusten yksilöpsykologiasta mielen virheisiin, hallusinaatioihin ja sosiaalisen marginaalin hypoteesiin, animismista ja antropomorfismista kognitiotutkimuksen intuitionvastaisuuteen sekä neurotieteen selitysmalleihin. Omaksi lähtökohdakseen Rancken on ottanut sen kulttuurintutkijoiden sisäistämän näkemyksen, että yksilön subjektiiviseen kokemukseen vaikuttaa myös sosiokulttuurinen konteksti. Ranckenin tutkimusasetelmaa motivoi huomio postsekulaarista yhteiskunnasta ja siitä ajatuksesta, että sekularisaatio eli maallistuminen ei olekaan tehnyt ihmisistä rationaalisempia, vaan kokemus yliluonnollisesta on edelleen elettyä todellisuutta monille (vrt. esim. Jager et al. 2016). Näiden kokemusten kulttuurisista arvotuksista kertonee paljon se, että jos tarrahenkien tai ufojen kohtaamisesta ei kannata yleisesti huudella, samanlaiset kokemukset kristillisessä kontekstissa saattavat kuitenkin monissa tapauksissa olla hyväksyttäviä.

Tekijä tarkastelee kokemuksen ja kerronnan yhteen kietoutuneisuutta sekä sitä, mitä ja miten yliluonnollisen kohtaamisesta kerrotaan. Ranckenin mukaan sosiaalitieteellinen tutkimus aiheesta on vähäistä. Tutkimuksellista taustaa olisi kuitenkin voinut vahvistaa enemmän folkloristiikan ja uskontotieteen tutkimuksilla memoraateista, uskomustarinoista sekä uskonnollisista ja mystisistä kokemuksista. Niissä kokemuksen, kielen, vuorovaikutuksen ja kulttuurisen kontekstin yhteenkietoutuneisuus on toki pitkään ollut varsin keskeinen.

\section{Haastatteluin koottu aineisto}

Tutkimuksessa on mittava laadullinen aineisto: 84 haastattelua, jotka on toteutettu kolmessa vaiheessa vuosina 2003-2009 pääosin Tampereen seudulla. Ne liittyvät tekijän opinnäytetöihin kandidaatin tutkielmasta väitöskirjaan. Kysymyksessä on siis pitkäjänteinen ja eri vaiheina kumuloitunut tutkimus. Rancken on pohtinut omaa tutkijan osuuttaan tarinan luomisessa - haastatteluilla kootut tarinathan eivät ole loogisia ja "puhtaita" lajinsa esimerkkejä. Jokaisen haastattelun tarinasta on esitetty tiivistelmä kirjan luvussa 2. Näin koko aineisto on tutkimuksen kannalta keskeiseltä sisällöltään esillä ja lukija saa hyvän kuvan siitä, millä kentällä liikutaan.

Aineiston käsittely on systemaattista ja kokonaisuudessaan hyvin kuvattu. Tarinoiden kriteerinä on ollut kertojan oma määrittely yliluonnollisesta sekä kokemuksen omakohtaisuus. Siinä mielessä ollaan folkloristisesti sanottuna nykyaikaisen memoraattiaineiston äärellä. Haastateltavista kaksi kolmasosaa on naisia, ja suurin osa haastatelluista keski-ikäisiä. Tutkimuksen aineistosta valtaosa linkittyy new age -tyyppiseen ja uushenkiseen transsendenssiin, mutta kokemuskertomuksissa heijastuu mielenkiintoisella tavalla myös kulttuurisesti vanhempia kerroksia kristinuskosta ja kansanuskosta. Rancken osoittaa, että vaikka uusi henkisyys sekoittuu helposti viihteeseen, myös viihteen elementit ja kuvasto puolestaan tarjoavat uusia aineksia uskomuksille. Tämä ei liene kuitenkaan täysin ennenkuulumatonta, sillä kuten esimerkiksi folkloristi Pasi Enges on tutkimuksessaan tenonsaamelaisesta 
uskomusperinteestä osoittanut, tarinat yliluonnollisen toiminnasta olivat ennenkin usein viihdettä (Enges 2012, 268). Mediat vain ovat muuttuneet.

Ranckenin kertojista monet tuntuvat mieltävän yliluonnollisen ja luonnollisen rinnakkaisina ja samaan todellisuuteen kuuluvina, eivät toisensa poissulkevina selitysjärjestelminä. Tämä on varsin tavallista myös elämyksellisyyttä ja Pyhän Hengen henkilökohtaista kohtaamista korostavan karismaattisen kristillisyyden piirissä, jossa varjeluskokemukset ja rukousvastaukset tuovat yliluonnollisen arkeen eikä kokijalla ole tarvetta vetää rajaa reaalimaailman ja yliluonnollisen välille, vaan kaikki tulkitaan samassa viitekehyksessä. Ranckenin haastateltavien oudot kokemukset kuitenkin poikkeavat usein arkisesta elämänmenosta, ja yllättävä poikkeuksellisuus vaatii kokijaa etsimään selitystä arkilogiikan tuolta puolen. Joissakin esimerkkikertomuksissa näkyy myös vaikeus nimetä koettua minkään kokijan tunteman viitekehyksen turvin. Näille selittämättömille numen-kertomuksille voi tulla jatkoa myöhemmin, jos sopiva selitysmalli löytyy (vrt. Honko 1980, 103 > Rudolf Otto: Das Heilige. München 1936).

Analyysin tuloksena on saatu esille kokemustyypit ja tarinatyypit. Kokemustyyppien luokittelu perustuu kokemuksen sisällölle. Kuitenkin eri sisältöisten kokemusten päällekkäisyys hämärtää luokitusta - kokemuksia voidaan niin ikään tulkita ja nimetä uudelleen ajan kuluessa (vrt. edellä). Omiksi kokemustyypeikseen on luokiteltu ennekokemukset, ruumiistairtautuminen, ufot ja humanoidit sekä henget ja voimat. Eniten on löytynyt viimeksi mainittua tyyppiä, jota edustaa yli puolet aineistosta. Mielenkiintoinen aineistosta esiin työntyvä piirre on myös hyvän ja pahan rinnakkaisuus ja samanaikaisuus. Kertomusten tarinatyypeiksi tutkija on nimennyt silminnäkijän, etsijän, oppilaan, pelastetun ja kamppailijan kategoriat. Narratiivisessa analyysissä on lisäksi huomioitu sanasto ja tyylilliset elementit tarkasteltaessa, millainen juonellinen jatkumo syntyy yliluonnollisen kokemuksen vaikutuksesta.

\section{Yliluonnollisen kokemuksen merkitykset ja vaikutukset}

Poikkeava tilanne, joka ei istu arkiajatteluun, vaatii selitystä, ja sille halutaan antaa tulkinta, joka merkitsee kertojan elämässä jotain olennaista. Monet Ranckenin aineiston kuvaukset saavat kokijoiltaan selityksiä uskonnon, ennen kaikkea kristinuskon viitekehyksestä ja sen liepeiltä. Tulkinnoissa liikutaan kuitenkin usein niin kutsutun vernakulaarin eli yksilöllisen, omaehtoisen ja epävirallisen uskonnon alueella (vrt. Bowman \& Valk 2014). Rancken on rakentanut luontevan teoreettisen lähestysmistavan haastatteluaineistonsa merkityksen annon tarkasteluun. Keskeisin auktoriteetti on psykologi Ray F. Baumeister ja kognitiivisen psykologian yksilönäkökulma, jota Baumeister on laajentanut ottamalla mukaan Peter Bergerin ja Thomas Luckmannin sosiaalisen konstruktionismin näkökulman merkityksellistämiseen sekä Ervin Goffmanin kehysanalyysin.

Yksilöllistä yliluonnollisen kokemistakin ohjaa kulttuurinen oppiminen merkityksistä ja tunteista sekä yksilön halu elää kulttuurin mukaisesti, koska se on emotionaalisesti palkitsevaa. Vastoin toimiminen taas herättää syyllisyyden tai epäonnistumisen tunteen, mikä liittyykin moniin aineiston tarinoihin. Varsinkin negatiivisen yliluonnollisen kokemuksen jättämät jäljet saattavat hiertää mielessä pitkään, koska niistä kertomisen voidaan nähdä kyseenalaistavan kertojan mielenterveyttä. Rancken on ottanut avuksi 'itseään toteuttavan profetian' käsitteen tarkastellessaan, miten usko tuottaa koettuja vaikutuksia. Tarinoiden ja kerronnan roolina on muovata ja jäsentää todellisuutta. Tässä kohden tullaan kielen potentiaaliin luoda 
kokemuksia, joita kulttuurinen tarinavaranto ja mallitarinat kehystävät. Monessa kohdassa tekijä palaa kysymykseen negatiivisen yliluonnollisen kokemuksen ja pahan käsittelyn vaikeuteen. Sellaisen sanoittamiseen ei valmiita kulttuurisia mallitarinoita ole aina helposti löydettävissä.

Tutkimuksen ansiona on ehdottomasti systemaattisesti toteutettu analyysi, jota elävöittävät runsaat aineistoesimerkit. Erityisesti oppilaan tarinat muistuttavat paljon kristillisiä johdatustarinoita, kuten myös pelastetun tarinat kääntymyskertomuksia ja (ihme)parantumistarinoita. Yliluonnollinen näyttääkin olevan tulkinnallisesti hyvin joustava kokemus. Rancken pohtii, miksi samanlainen kokemus saa niin erilaisia tulkintoja, ja jatkaa analyysiä vertailemalla tarinatyyppejä kokemuksen sisällön, kuluneen ajan, tunteiden ja sosiaalisten yhteyksien suhteen. Kuten tekijä toteaa, kokemuksen tulkinta, merkitys ja vaikuttavuus liittyvät toisiinsa sekä muodostavat psykologisen ja sosiaalisen todellisuuden ihmisten välisessä vuorovaikutuksessa.

\section{Yliluonnollinen ja elämä}

Jeena Ranckenin tutkimus on jännittävä, päivitetty näkymä siihen, kuinka tarina koetusta yliluonnollisesta kasvaa osaksi elämän tapahtumia ja miten siihen punoutuu mukaan kulttuurisia aineksia. Nämä kokemukset voivat toimia yksilöiden ja ryhmien inspiraation lähteenä ja motivaationa riippuen niille annetuista merkityksistä. Ne saattavat jopa käynnistää elämän muutoksen. Rancken kuitenkin näkee kokemusta tärkeämpinä niiden tulkinnat ja merkitykset. Merkillepantavaa on, että ensimmäinen kokemus yliluonnollisesta ei ole välttämättä kokijalle se merkittävin, vaan vasta myöhemmät kokemukset, jolloin niiden "lukutaito" on kehittynyt. Tämä seikka rinnastuu itse haastatelemiini kristittyihin uskoviin, joille kääntymyksessä ei useinkaan ollut mitään dramatiikkaa, vaan heille tärkeämmät kokemukset seurasivat vasta paljon myöhemmin, kun kristillinen tulkintakehys oli opittu (Hovi 1997).

Tutkimuksen tulokset ovat pääosin uskomusperinteiden tutkimukselle tuttuja. Vaikka haastateltavien kokemukset olivat subjektiivisia, ne eivät silti olleet yksilöpsykologisia, vaan noudattivat malleja ja välittyivät sosiaalisesti. Ne heijastavat myös itseään toteuttavaa ennustetta - usko johonkin tuottaa sen suuntaisia kokemuksia, ja kokemukset ja tulkinnat vahvistavat edelleen kokijan uskoa yliluonnolliseen. Tekijä nostaa tutkimuksellaan esiin tärkeän seikan, nimittäin sen, että kertominen yliluonnollisesta on varsin usein tabuoitu ja arkaluonteinen asia. Siitä voi jopa seurata sanktioita, erityisesti negatiivisesta yliluonnollisesta kertomisesta, ja se on mielletty pikemminkin mielenterveysongelmaksi kuin henkisyydeksi. Siihen voi liittyä ankaraa ristivetoa, halua puhua ja pelkoa tulla leimatuksi.

Siitä huolimatta, että tässä teoksessa on ohitettu koko joukko merkittävää perinnetieteellistä tutkimusta yliluonnollisen kohtaamisesta ja siihen liittyvästä kertomusperinteestä, on kirjoittaja osoittanut ihailtavaa pitkäjänteisyyttä sekä taitoa käydä läpi laaja kirjo aihetta käsittelevää moniulotteista tutkimusta ja saattaa se oivaltavaan keskusteluyhteyteen oman aineistonsa kanssa. 


\section{Kirjallisuutta}

Bowman, Marion \& Ülo Valk 2014: Vernacular Religion in Everyday Life: Expressions of Belief. Abingdon: Routledge.

Enges, Pasi 2012:"Minämelkein uskon". Yliluonnollinenja sen kohtaaminen tenonsaamelaisessa uskomusperinteessä. Turku: Turun yliopisto.

Honko, Lauri 1980: Uskontotieteen näkökulmia. Porvoo: WSOY.

Hovi, Tuija 1997: Kääntymiskertomukset haastatteluissa. - Katarina Eskola \& Eeva Peltonen (toim.), Aina uusi muisto. Kirjoituksia menneen elämisestä meissä. Nykykylttuurin tutkimusyksikön julkaisuja 54. Jyväskylä: Jyväskylän yliopisto.

Jager, Colin, Guido Vanheeswijk \& Florian Zemmin (eds.) 2016: Working with A Secular Age: Interdisciplinary Perspectives on Charles Taylor's Master Narrative. Berlin, Boston: De Gruyter.

Sundén, Hjalmar 1971: Religionen och rollerna. Ett psykologiskt studium av fromheten. Stockholm: Verbum. [1959]

Filosofian tohtori Tuija Hovi on uskontotieteen dosentti Turun yliopistossa. 